\title{
Antifungal effect of sesame medicinal herb on Candida Species: original study and mini-review
}

\author{
Fatemeh Lavaee', Maryam Moshaverinia ${ }^{1}$, Seyed Ali MalekHosseini², Akram Jamshidzade ${ }^{3}$, \\ Maryam Zarei ${ }^{1}$, Hadis Jafarian ${ }^{4}$, Pardis Haddadi ${ }^{5}$, Parisa Badiee ${ }^{4 *}$
}

\begin{abstract}
${ }^{1}$ Oral and Dental Disease Research Center and Oral and Maxillofacial Medicine Department, School of Dentistry, Shiraz University of Medical Sciences, Shiraz, Iran, ${ }^{2}$ Transplant Research Center, Nemazee Hospital, Shiraz University of Medical Sciences, Shiraz, Iran, ${ }^{3}$ Pharmacology and Toxicology Department, School of Pharmacy, Shiraz University of Medical Sciences, Shiraz, Iran, ${ }^{4}$ Professor Alborzi Clinical Microbiology Research Center, Nemazee Hospital, Shiraz University of Medical Sciences, Shiraz, Iran, ${ }^{5}$ Department of Periodontology, Faculty of Dentistry, Lorestan University of Medical Sciences, Khorramabad, Iran
\end{abstract}

\begin{abstract}
The aim of this study was to evaluate the antifungal susceptibility patterns of three antifungals, methanolic extracts and N-hexane oil of sesame seeds on C. albicans and C. glabrata, isolated from oral cavity of liver transplant recipients. The results were compared with other reports to develop a mini review as well. Candida species were isolated from liver transplant recipients. To evaluate the antifungal activity of sesame seed oil and methanolic extract, fluconazole, caspofungin and nystatin, the corresponding minimum inhibitory concentrations were determined by CLSI M27-A3 standard method. Minimum fungicidal concentration was also evaluated. The most prevalent species was C. albicans, followed by C. glabrata. Findings indicated sensitivity to antifungal agents and resistance to methanolic extract and N-hexane oil for all C. albicans and C. glabrata isolates. The rate of Candida colonization in the oral cavity of liver transplant recipients was high. Our results revealed that the methanolic and N-hexan extracts of sesame seeds are not effective on C. albicans and C. glabrata species, isolated from the patients. The sesame seed oil pulling and mouthwash cannot effectively cleanse and remove the Candida species in the mouth. Investigation of other medicinal plants or other parts of sesame like leaves and roots are suggested.
\end{abstract}

Keywords: Candida species/ antifungal susceptibility. Sesame/study. Liver transplant.

\section{INTRODUCTION}

Sesame seed oil is popular edible oil in some parts of the world like North India, Iran, and Japan (Bedigian, 2004). It was cultivated since more than 5000 years ago and the Sesame radiatum and Sesame indicum are usually cultivated for their seeds and leaves. Antifungal and antibacterial activities were reported for sesame oil (Shittu et al., 2006; Shittu et al., 2007). Oral candidiasis is an opportunistic infection with frequency of $65 \%$ in the elderly wearing dentures (Nurdiana, Jusri, 2009) and $16.7 \%$ in patients with hematologic disorders (Badiee et al., 2017). Candida species are commensal organism in human oral cavity and can transfer to pathogenic form (oral or systemic candidiasis) in immunocompromised patients (Badiee, Alborzi, 2011; Sharon, Fazel, 2010; Tarçın,

\footnotetext{
*Correspondence: P. Badiee. Prof. Alborzi Clinical Microbiology Research Center, Namazee Hospital Zand Ave. Shiraz University of Medical Sciences, Shiraz, Iran. Postal code: 7193711351. Tel: 98 71-3647-4292/ Fax:98 71-3647-4303. E-mail: badieep@gmail.com 6
}

2011). During the last two decades, resistance to common antifungal drugs in Candida species has increased (Badiee et al., 2011; Badiee et al., 2017b). Nystatin is a routine antifungal agent used in the clinics for the prevention and treatment of oral candidiasis. Fluconazole and caspofungin are important antifungals against human pathogenic yeasts with some side effects and toxicity. The effective and safe antifungal agents against fungi, especially Candida species, are needed.

Some investigations have introduced new herbal products with fewer side effects and lower costs. However, there are some controversies about the antifungal properties of such products (Makki, Olama, Holail, 2012; Thaweboon, Nakaparksin, Thaweboon, 2011). Sesame oil can be extracted by a number of methods, depending on the materials and equipment available. The aim of this study was to evaluate antifungal susceptibility patterns of three antifungals, methanolic extracts and $\mathrm{N}$-hexane oil of sesame seeds on C. albicans and C. glabrata, isolated from oral cavity of liver transplant recipients by micro- 
dilution standard CLSI M27 A3 method. The results could be helpful to the best management of oral candidiasis in such patients. The present study findings were compared with other reports to develop a mini-review as well.

\section{MATERIAL AND METHODS}

\section{Test organism}

This study was carried out on liver transplant recipients admitted to Nemazee hospital, Shiraz University of Medical Sciences, from January to June 2016. Patients had not received any systemic or local antifungal drugs for one month prior to sampling. A sterile swab was rubbed through the mouth cavity and cultured on Sabouraud Dextrose Agar (Merck, Germany) with chloramphenicol to inhibit the growth of normal oral microflora. Demographic data of the patients were collected from their files. Standard Candida species (C. glabrata ATCC 2001) was examined along with the test samples processing.

\section{Ethical considerations}

This study was approved by Ethics Committee at Professor Alborzi Clinical Microbiology Research Center, Shiraz University of Medical Sciences, Shiraz, Iran (Ethic Code 1822).

\section{Identification of the isolated strains}

The plates were incubated at $24{ }^{\circ} \mathrm{C}$ and monitored for fungal growth every day. Candida species isolated from primary cultures, were subcultured to ensure the purity. For DNA extraction, a suspension of the isolated fungi in distilled water $\left(10^{5}\right.$ Candida $\left./ \mathrm{mL}\right)$ was prepared in sterile tubes and fungal cell walls were broken using a sonicator (Hielscher, Germany). DNA was extracted by Invisorb (Berlin, Germany) according to the manufacturer's instructions and identified using restriction fragment length polymorphism PCR (RFLP).

PCR was performed using PCR mixture $(5 \mu \mathrm{L}$ of $10 x$ reaction buffer, $1.5 \mathrm{mM} \mathrm{MgCl}_{2}, 0.4 \mathrm{mM}$ dNTPs, $2.5 \mathrm{U}$ of DNA Taq polymerase (Cinnagen, Germany), $30 \mathrm{pmol}$ of each ITS1 (5 ' -TCC GTA GGT GAA CCT GCG G-3') and ITS4 ( 5 ' -TCC TCC GCT TAT TGA TAT GC-3') primers and $3 \mu \mathrm{L}$ of the extracted DNA in a final volume of $50 \mu \mathrm{L}$. The PCR conditions were as follows: $94^{\circ} \mathrm{C}$ for 5 min, followed by 35 cycles at $94{ }^{\circ} \mathrm{C}$ for $30 \mathrm{~s}, 55^{\circ} \mathrm{C}$ for $45 \mathrm{~s}$, and $72{ }^{\circ} \mathrm{C}$ for $1 \mathrm{~min}$, with a final step at $72{ }^{\circ} \mathrm{C}$ for 7 min (Mirhendi et al., 2006). $10 \mu \mathrm{L}$ of each PCR product was digested with the restriction enzyme Msp I (RR) for two hours at $37^{\circ} \mathrm{C}$. Electrophoresis was performed on $2 \%$ agarose gel (Sigma, Germany).

\section{Extraction of sesame seeds}

Sesame seeds were obtained from market in Shiraz, Iran in July 2016 and sesame seed oil was extracted by Soxhelet extraction method. Crude sesame seeds were air dried for 2 weeks and ground into powder using a grinder. The powders $(20 \mathrm{~g})$ were added to $100 \mathrm{~mL}$ of absolute $\mathrm{N}$-hexane and $100 \mathrm{~mL}$ of methanol $(80 \% \mathrm{v} / \mathrm{v})$. The hexane oil extracted with Soxhlet extraction apparatus (SigmaAldrich, Germany). Methanol extracts were filtered by Whatman No 1 filter papers (Whatman, USA) and concentrated using a EYELA rotary evaporator (N-1000, Japan), and freeze-dried using the Edwards freeze dryer (Edwards High Vacuum International Crawley, Sussex, England). Stock concentration of $10 \%$ in diluted dimethyl sulfoxide in Roswell Park Memorial Institute (RPMI 1640 , Sigma, Germany) was prepared for the oil materials (Randhawa, 2008).

\section{Standard antifungal}

The standard powder of fluconazole, caspofungin and nystatin were obtained from Sigma-Aldrich (St Louis, MO, USA).

\section{Standardization of micro-organisms}

To determine the antifungal activity of agents, the CLSI M27-A3 standard method was used for extracts and three antifungal agents (Wayne, 2008). The Candida species suspension was adjusted spectrophotometrically to $0.5 \mathrm{McF}$ arland (final inoculums concentrations $1.5 \times 10^{6} \mathrm{CFU} / \mathrm{mL}$ ) and diluted 1:1000 in RPMI 1640. Ten serial dilutions of each antifungal agent and extract were prepared and mixed with $100 \mu \mathrm{L}$ of the fungal suspensions. Negative control (well without yeast) and positive control (well without extract, oil or antifungal) were used in each serial of the test. The plates were sealed and incubated at $35^{\circ} \mathrm{C}$ for $24 \mathrm{~h}$ and the MIC end-points were determined visually. The MIC is defined as the lowest concentration that causes $50 \%$ inhibition of visible fungal growth, compared with positive control. Final concentrations of methanolic and $\mathrm{N}$-hexan solutions of sesame seeds were between 20 and $0.04 \mu \mathrm{g} / \mathrm{mL}$. Concentration range for fluconazole was from 64 to $0.125 \mu \mathrm{g} / \mathrm{mL}$, nystatin $18.5-0.035 \mu \mathrm{g} / \mathrm{mL}$ and caspofungin from 16 to $0.032 \mu \mathrm{g} / \mathrm{mL}$. 


\section{Minimum Fungicidal Concentration (MFC)}

To detect MFC, $100 \mu \mathrm{L}$ of each well and negative and positive controls were cultured on sabouraud dextrose agar plates in triplicate and the rates of yeast growth were counted after 48 hours. The MFC value is the lowest concentration of each extract that inhibits the $99.9 \%$ growth of yeast, compared to positive control.

\section{Statistical analysis}

Statistical analysis was performed using SPSS 15software (Statistical Product and Services Solutions, Inc, Chicago, IL, USA). P-value $\leq 0.05$ was set as the significant threshold for statistical analysis.

\section{RESULTS AND DISCUSSION}

During a six-month period, 65 liver transplant recipients including 25 females (39\%) and 40 males (61\%) were enrolled. Mean age of the participants was 29.8 years. Forty-eight Candida species were isolated from 41 recipients $(41 / 65,63 \%)$, while in some more than one species was isolated. The most prevalent species was C. albicans $(34,70.8 \%)$, followed by C. glabrata $(9$, $18.8 \%$ ), and other Candida species including C. kefyr, $C$. tropicalis, $C$. intermadia $(5,10.4 \%)$ (Table I). The most isolated species (including C. albicans and C. glabrata) were used in this study. The findings indicated no antifungal effect for either methanolic extract or $\mathrm{N}$-hexane oil against all C. albicans and C. glabrata isolates. The MIC50 and MIC90 values for both extracts and nystatin were $20 \mu \mathrm{g} / \mathrm{mL}$ and $0.035 \mu \mathrm{g} / \mathrm{mL}$ in all species, respectively. The MIC90 values of fluconazole for C. albicans and C. glabrata were $0.5 \mu \mathrm{g} / \mathrm{mL}$ and $2 \mu \mathrm{g} / \mathrm{mL}$, respectively. MIC 90 values of caspofungin for C. albicans and C. glabrata were $0.125 \mu \mathrm{g} / \mathrm{mL}$ and $0.5 \mu \mathrm{g} / \mathrm{mL}$, respectively (Table II). There was a significant difference $(p>0.05)$, observed between antifungal activity of sesame seed extract, oil and the three antifungal agents. No antifungal inhibitory of growth or fungicidal activity was seen and yeast growth was observed on all the treated wells.

The rate of oral Candida colonization in this study was $63 \%$ and $C$. albicans was the most prevalent isolated species (70.8\%). These rates in Nazhvani et al. (2016) were reported $67.4 \%$ and $75 \%$, respectively. The isolated species in this study were sensitive to all antifungal agents and resistant to the sesame methanolic extracts and hexane oil. In liver transplant recipients, use of antifungal agents with low toxicity and high efficacy is important due to their special conditions (many drugs metabolized in the liver). Studies on medicinal plants have demonstrated their antifungal activities, leading to the development of more potent antifungal drugs (Shittu et al., 2006; Shittu et al., 2007). Sesame is reputed in folk medicine and in this study no antifungal activity of methnolic extract and n-hexane oil of sesame seeds on C. albicans and C. glabrata, clinically isolated from liver transplant recipients, was observed.

There are many controversies about antifungal activity of sesame extracts. According to the literature, the antifungal activity of sesame is dependent on the type of extraction (oil, ethanol, methanol, hexane and aqueous extract) and part of the plant used in the study (leaves, seeds) (Table III). Also, the methodology used in determining sensitivity in the reported data includes Agarwell diffusion (Shittu et al., 2007; Shittu, Shittu, 2012), disc diffusion or microdilution method (Ogawa, Nishio, Okada, 2014). In a study by Shittu et al. (2006), ethanoic leave extract of sesame mildly inhibited $C$. albicans growth while aqueous extract showed no inhibitory effect. In another study, stronger antifungal properties were reported for ethanolic extract of sesame leaves than for its aqueous extract (Shittu, Shittu, 2012). Shittu 2008 reported the methanolic extracts of sesame leaves had no antifungal effect against $C$. albicans while the ethanolic and aqueous extracts exhibited inhibitory growth effect (Thaweboon, Nakaparksin, Thaweboon, 2011).

In the present study, no antifungal activitiy was observed in the oil extract of sesame seed. Similarly, no antifungal activity was reported for sesame oil in the literature (Makki, Olama, Holail, 2012; Thaweboon, Nakaparksin, Thaweboon, 2011). Ogawa, Nishio and Okada (2014) evaluated the effects of sesame oil and some other edible oils on 5 Candida species. They reported that sesame oil can inhibit the growth of both yeast and mycelium of fungi. Investigation into the antifungal activity of sesame leaves, stems and roots on filamentus fungi showed that most of the extracts had inhibitory effects on the tested filamentus fungi but root and leaf extracts enhanced the growth of Alternaria sesami, and Fusarium oxysporum, as compared to the controls (Syed et al., 2015)."The inhibition effects of diethylether, chloroform and hexane fractions were higher than that of ethanol fraction remaining after extraction with the other solvents" (Syed et al., 2015).

There have been some studies about physicochemical compound of sesame extracts. The chemical compounds of sesame oil by Gas Chromatography/ Mass Spectra system contain protein, carbohydrate, vitamin, ash, unsaturated fatty acids (oleic, linoleic), 
saturated fatty acids (palmitic and stearic) and minerals (Ca, P, K, Mg, Na, Fe, low amount of $\mathrm{Zn}$ ) (Alyemeni, Basahy, Sher, 2011; Borchani et al., 2010; Kanu, 2011). According to the literature, Phenolic ingredients, flavonoid subfractions, punicalin, punicalagin, and tannins are the main ingredients responsible for the plant antimicrobial activity (Anibal et al., 2013; Shahat et al., 2001). However, none of such components has been identified in the analytical studies of sesame extracts. Future studies are needed for the identification of antifungal components in the sesame oil and extracts.

The antifungal activity of sesame hairy roots due to
TABLE I - Candida species isolated from oral specimens of liver transplant patients

\begin{tabular}{lc}
\hline Candida Species & Number/percent \\
\hline C. albicans & $34(70.8)$ \\
C. glabrata & $9(18.8)$ \\
C. kefyr & $2(4.1)$ \\
C. parapsilosis & $1(2.1)$ \\
C. tropicalis & $1(2.1)$ \\
C. intermedia & $1(2.1)$ \\
\hline Total & $48(100)$ \\
\hline
\end{tabular}

TABLE II - MIC50 and MIC90 values of methanolic and N-hexane extracts of sesame seeds and antifungals for the isolated Candida species

\begin{tabular}{lcccccc}
\hline Candida species & MIC & $\begin{array}{c}\text { Methanolic } \\
\text { extracts }\end{array}$ & N-hexane oil & Nystatin & Fluconazole & Caspofungin \\
\hline \multirow{2}{*}{ Candida albicans } & MIC50 $(\mu \mathrm{g} / \mathrm{mL})$ & 25 & 25 & 0.035 & 0.5 & 0.063 \\
& MIC90 $(\mu \mathrm{g} / \mathrm{mL})$ & 25 & 25 & 0.035 & 0.5 & 0.125 \\
\hline \multirow{2}{*}{ Candida glabrata } & MIC50 $(\mu \mathrm{g} / \mathrm{mL})$ & 25 & 25 & 0.035 & 2 & 0.250 \\
& MIC90 $(\mu \mathrm{g} / \mathrm{mL})$ & 25 & 25 & 0.035 & 2 & 0.500 \\
\hline
\end{tabular}

TABLE III - The comparative antifungal activity of different parts and extracts of sesame seed

\begin{tabular}{|c|c|c|c|c|c|}
\hline Reference & Plant & plant part & microorganism & Type of extract & Inhibitory activity \\
\hline (Shittu et al., 2006) & Sesame radiatum & leaves & Candida albicans & $\begin{array}{l}\text { Ethanolic } \\
\text { Aqueous }\end{array}$ & $\begin{array}{c}\text { Mildly } \\
\text { Negative }\end{array}$ \\
\hline (Shittu et al., 2007) & Sesame radiatum & leaves & Candida albicans & $\begin{array}{l}\text { Methanolic } \\
\text { Ethanolic } \\
\text { Aqueous } \\
\end{array}$ & $\begin{array}{l}\text { Negative } \\
\text { Positive }^{+} \\
\text {Positive }^{4+} \\
\end{array}$ \\
\hline $\begin{array}{l}\text { (Thaweboon Nakaparksin, } \\
\text { Thaweboon, 2011) }\end{array}$ & Sesame sp. & oil & Candida albicans & & Negative \\
\hline $\begin{array}{l}\text { (Makki, Olama, Holail, } \\
\text { 2012) }\end{array}$ & Sesame sp. & oil & Candida albicans & & Negative \\
\hline (Shittu, Shittu, 2012) & Sesamum radiatum & leaves & Candida albicans & $\begin{array}{l}\text { Methanolic } \\
\text { Ethanolic } \\
\text { Aqueous }\end{array}$ & $\begin{array}{l}\text { Negative } \\
\text { Positive }^{2+} \\
\text { Positive }^{+}\end{array}$ \\
\hline $\begin{array}{l}\text { (Ogawa, Nishio, Okada, } \\
\text { 2014) }\end{array}$ & & oil & Candida albicans & & Positive \\
\hline (Bankole et al., 2007) & $\begin{array}{c}\text { Combined } \\
\text { Sesame radiatum \& } \\
\text { Sesame indicum } \\
\end{array}$ & leaves & Candida albicans & $\begin{array}{l}\text { Methanolic } \\
\text { Ethanolic } \\
\text { Aqueous } \\
\end{array}$ & $\begin{array}{l}\text { Positive }^{3+} \\
\text { Positive }^{+} \\
\text {Positive }^{4+} \\
\end{array}$ \\
\hline $\begin{array}{l}\text { (Tabassum, Vidyasagar, } \\
\text { 2014) }\end{array}$ & Sesame sp. & oil & Candida albicans & $\begin{array}{c}\text { Hexane } \\
\text { Methanolic }\end{array}$ & $\begin{array}{l}\text { Positive } \\
\text { Positive } \\
\end{array}$ \\
\hline (Uniyal et al., 2012) & Sesame sp. & oil & $\begin{array}{c}\text { Aspergillus niger } \\
\text { Aspergillus } \\
\text { fumigatus }\end{array}$ & & Moderately \\
\hline $\begin{array}{l}\text { (Shirurkar, Wahegaonkar, } \\
\text { 2012) }\end{array}$ & Seasame sp. & oil & $\begin{array}{c}\text { Aspergillus } \\
\text { Filamentus fungi }\end{array}$ & & Negative \\
\hline
\end{tabular}

${ }^{+}$Full concentration presents anti- Candida activity ${ }^{4+}$ Diluted concentration presents anti- $C$ andida activity 
three anthraquinones, anthrasesamones $\mathrm{A}, \mathrm{B}$ and $\mathrm{C}$ and chlorinated red naphthoquinone pigment were reported (Begum, Furumoto, Fukui, 2000; Furumoto et al., 2003). The sesame flowers are purple to whitish and have been used to prepare perfumes in Africa (Morris et al., 2002). The antifungal activities of sesame roots and leaves were investigated against some the fungi like Macrophomina phaseolina, Alternaria sesame and Fusarium oxysporum. However, the results of this study demonstrated that compared to the control, root and leaf extracts can enhance the growth of $A$. sesame by and $F$. oxysporum, respectively (Syed et al., 2015).

\section{CONCLUSION}

Taking into account the results, we can conclude that the rate of Candida colonization in the oral cavity of liver transplant recipients is high. Use of a mouth wash with high efficacy and low toxicity is essential. Our results revealed that the methanolic and $\mathrm{N}$-hexan extracts of sesame seeds are not effective on C. albicans and $C$. glabrata species, isolated from the patients. The sesame seeds oil pulling or mouthwash which contains sesame extract cannot effectively cleanse and remove the Candida species in the mouth.

\section{ACKNOWLEDGEMENT}

The authors thank the Vice-Chancellory of Research Shiraz University of Medical Science for supporting this research (Grant\# 1822). This article is based on the thesis by Maryam Zarei. Our thanks go to Hassan Khajehei for copy editing of the manuscript.

\section{REFERENCES}

Alyemeni MN, Basahy AY, Sher H. Physico-chemical analysis and mineral composition of some sesame seeds (Sesamum indicum L.) grown in the Gizan area of Saudi Arabia J Med Plant Res. 2011;5(2):270-274.

Anibal PC, Peixoto ITA, Foglio MA, Höfling JF. Antifungal activity of the ethanolic extracts of Punica granatum L. and evaluation of the morphological and structural modifications of its compounds upon the cells of Candida spp. Braz J Microbiol. 2013;44(3):839-848.

Badiee P, Alborzi A. Assessment of a real-time PCR method to detect human non-cryptococcal fungal meningitis. Arch Iran Med. 2011;14(6):381.
Badiee P, Alborzi A, Shakiba E, Farshad S, Japoni A. Susceptibility of Candida species isolated from immunocompromised patients to antifungal agents/Sensibilité aux antifongiques des espèces de Candida isolées chez des patients immunodéprimés. East Mediterr Health J. 2011;17(5):425.

Badiee P, Zareifar S, Haddadi P, Jafarian H. Incidence of fungal infections in pediatric patients with hematologic neoplasms. Arch Pediatr Infect Dis. 2017a;5(3):e41317.

Badiee P, Choopanizadeh M, Moghadam AG, Nasab AH, Jafarian H, Shamsizadeh A, Soltani J. Antifungal susceptibility patterns of colonized Candida species isolates from immunocompromised pediatric patients in five university hospitals. Iranian J Microbiol. 2017b;9(6):363-71

Bankole MA, Shittu LAJ, Ahmed TA, Bankole MN, Shittu RK, Terkula K, et al. Synergistic antimicrobial activities of phytoestrogens in crude extracts of two sesame species against some common pathogenic microorganisms. Afr J Tradit Complement Altern Med. 2007;4(4):427-433.

Bedigian D. Cover Article: History and Lore of Sesame in Southwest Asia. Econ Bot. 2004;58(3):330-353.

Begum S, Furumoto T, Fukui H. A new chlorinated red naphthoquinone from roots of Sesamum indicum. Biosci Biotechnol Biochem. 2000;64(4):873-874.

Borchani C, Besbes S, Blecker CH, Attia H. Chemical characteristics and oxidative stability of sesame seed, sesame paste, and olive oils. J Agric Sci Technol. 2010;12:585-596.

Furumoto T, Iwata M, Hasan AF, Fukui H. Anthrasesamones from roots of Sesamum indicum. Phytochemistry. 2003;64(4):863866.

Kanu PJ. Biochemical analysis of black and white sesame seeds from China. Am J Biochem Mol Biol. 2011;1(2):145-157.

Makki S, Olama Z, Holail H. Anti-fungal activity of plant oils against oral clinical isolates of Candida albicans in Lebanese community. Topclass J Microbiol. 2012;1(2):42-54.

Mirhendi H, Makimura K, Khoramizadeh M, Yamaguchi H. A one-enzyme PCR-RFLP assay for identification of six medically important Candida species. Nippon Ishinkin Gakkai Zasshi. 2006;47(3):225-229. 
Morris JB. Food, industrial, nutraceutical, and pharmaceutical uses of sesame genetic resources. Trends in New Crops and New Uses. 2002:153-156.

Nazhvani AD, Haddadi P, Badiee P, Malekhoseini SA, Jafarian H. Antifungal effects of common mouthwashes on candida strains colonized in the oral cavities of liver transplant recipients in South Iran in 2014. Hepat Mon. 2016;16(1):e31245.

Nurdiana N, Jusri M. Pseudomembranous candidiasis in patient wearing full denture. Maj Ked Gi Ind. 2009;42(2):60-64.

Ogawa T, Nishio J, Okada S. Effect of edible sesame oil on growth of clinical isolates of Candida albicans. Biol Res Nurs. 2014;16(3):335-343.

Randhawa MA. Dimethyl Sulfoxide (DMSO) Inhibits the germination of candida albicans and the arthrospores of trichophyton mentagrophytes. Nippon Ishinkin Gakkai Zasshi. 2008;49(2):125-128.

Shahat AA, Pieters L, Apers S, Nazeif NM, Abdel-Azim NS, Berghe DV, et al. Chemical and biological investigations on Zizyphus spina-christi L. Phytother Res. 2001;15(7):593-597.

Sharon V, Fazel N. Oral candidiasis and angular cheilitis. Dermat Ther. 2010;23(3):230-242.

Shirurkar DD, Wahegaonkar NK. Antifungal activity of selected plant derived oils and some fungicides against seed borne fungi of maize. Eur J Exp Biol. 2012;2(5):1693-1696.

Shittu LAJ, Bankole MA, Ahmed T, Aile K, Akinsanya MA, Bankole MN, et al. Differential antimicrobial activity of the various crude leaves extracts of Sesame radiatum against some common pathogenic micro-organisms. Sci Res Essay. 2006;1(3):108-111.
Shittu LAJ, Bankole MA, Ahmed T, Bankole MN, Shittu RK, Saalu CL, et al. Antibacterial and antifungal activities of essential oils of crude extracts of Sesame radiatum against some common pathogenic microorganisms. Iran J Pharmacol Ther. 2007;6(2):165-170.

Shittu LAJ, Shittu RKM. Improved fertility potential and antimicrobial activities of sesame leaves phytochemicals. Phytochemicals as Nutraceuticals-Global Approaches to Their Role in Nutrition and Health: InTech; 2012.

Syed RN, Laurentin H, Splivallo R, Karlovsky P. Antifungal properties of extracts of Sesame (Sesamum indicum). Int J Agric Biol. 2015;17(3):575-581.

Tabassum N, Vidyasagar GM. Invitro antimicrobial activity of edible oil against human pathogens causing skin infection. Int J Pharm Sci Res. 2014;5(10):4493.

Tarçın BG. Oral candidosis: aetiology, clinical manifestations, diagnosis and management. J Marmara Univ Inst Health Sci. 2011;1(2):140-148.

Thaweboon S, Nakaparksin J, Thaweboon B. Effect of oilpulling on oral microorganisms in biofilm models. Asia J Public Health. 2011;2(2):62-66.

Uniyal V, Bhatt RP, Saxena S, Talwar A. Antifungal activity of essential oils and their volatile constituents against respiratory tract pathogens causing Aspergilloma and Aspergillosis by gaseous contact. J Appl Nat Sci. 2012;4(1):65-70.

Wayne P. Clinical and Laboratory Standards Institute: Reference method for broth dilution antifungal susceptibility testing of yeasts; approved standard-; CLSI document M27-A3. CLSI 2008a. 2008;28:6-12.

Received for publication on $12^{\text {th }}$ August 2017 Accepted for publication on $16^{\text {th }}$ April 2018 